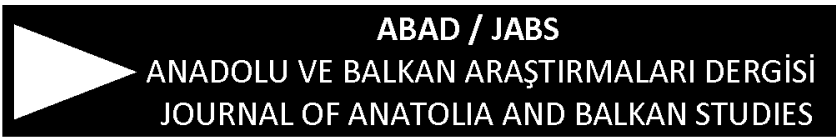

ABAD, 2019; 2(4): 245-258

ISSN: 2618-6004

abad $a$ nku.edu.tr

e-ISSN:2636-8188

DOI: 10.32953/abad.535965

\title{
INTERNAL AND EXTERNAL REASONS OF THE BREAKUP OF THE YUGOSLAVIA Sait YAĞCI*
}

Abstract: In this article, the break-up of Yugoslavia which was established in Balkan peninsula will be analyzed in detail. My analyze is going to focus more on a wide range of reasons for the collapse of Yugoslavia. In this direction, I will examine the economic, social, political and foreign(external) reasons for the dissolution of Yugoslavia. As can be understood, Balkans lived the golden age under Yugoslavia, especially in the period of Tito. However, in the wake of the death of Tito, Balkans found itself in a tremendous mess. In this article, my goal is to explain the reasons for the dissolution of Yugoslavia and shed light on the developments in the area between the years of 1945 and 1992. questions will be answered: 1) what is the most important factor in the disintegration of Yugoslavia. 2) did external factors play a vital role in the dissolution of Yugoslavia

Keywords: Yugoslavia, Tito, Balkans, National Security department

\section{YUGOSLAVYA'NIN ÇÖKÜŞÜNÜN İÇ VE DIŞ NEDENLERI}

Öz: Bu makalede, Balkan yarımadasında kurulan Yugoslavya'nın dağılıșı, detaylı bir șekilde analiz edilecektir. Dolaysıyla bu makale, Yugoslavya'nun yıkılıș nedenlerinin üzerine odaklanacaktır. $\mathrm{Bu}$ bağlamda, Yugoslavyanın dağılıșının ekonomik, sosyali politik ve dış nedenlerini inceleyeceğim. Anlaşılacağı gibi, Balkanlar, özellikle Tito döneminde altın çağını yaşamıştır. Ancak, Tito'nun ölümünden sonra, Balkanlar kendini bir karışıklık içinde bulmuşlardır. Bu makalede, amacım 1945 ve 1992 yılları arasındaki bölgedeki gelişmelere 1şı tutmak ve yugoslavya'nın dağılıș nedenlerini açıklamatır. benim hipotezim, Yugoslavya'nın dağılışındaki en büyük etken dıș etkenlerden ziyade, ülke içerisindeki meydana gelen olaylardır. Bu makalede

\footnotetext{
* Ph.d candidate, Sait Yağc1,International University of Sarajevo,saityağc1@gmail.com
} 
Yağcı, S. (2019). Internal and External Reasons of The Breakup of The Yugoslavia. ABAD, 2(4), 245-258.

Şu sorulara cevap aranacaktır: 1) Yugoslavya'nın dağılmasında en büyük etken nedir. 2) dıș etkenler, ülkenin dağılmasında etkin bir rol oynamışmıdır.

Anahtar Kelimeler: Yugoslavya, Tito, Balkanlar, Ulusal güvenlik bölümü

\section{Introduction}

When the reasons for wars worldwide are studied, it is seen that the majority of these reasons are religion, ethnicity or race-related. Similarly, when looking at the causes of dissolution of Yugoslavia, they can be grouped under four headings; Nationalism, Economic reasons International politics, Cultural arguments. As Yugoslavia grew weaker, the ethnical groups within the country would, one after another, found their own independent states; because each ethnical group wanted to found a republic where they are the majority and not to be ruled by others. (Jovic,2001)

Serbians, especially during the disintegration stage of Yugoslavia, tried to stop the disintegration by taking important steps. Serbians' aim was to unite all ethnical groups within Yugoslavia, whom they considered their kin, under one roof. With this purpose, Serbians occupied important ranks in military and government which were the two important power centers of the federation. However, the fact that other ethnical groups were ignored and neglected was going to accelerate the disintegration of Yugoslavia and pave the way for the foundation of new states. In addition to this, some ethnical groups did not feel any bonds with Yugoslavia or with Slavic race. On the contrary, especially Slovenes and Croats felt that they belonged with Central Europe due to religious and economic ties; let alone considering themselves Slavic. As a result of this, it seemed to be impossible to live under the same roof with Serbians. Through history, the thought of establishing favorable relations and unity with Europe started to gain more support, and the oppressive approaches of ultranationalist Serbians gave Croats and Slovenes important reasons for their independence.

Foreign reasons have an important role in the disintegration of Yugoslavia as much as the domestic reasons do. Especially Germany's attitude would be among the reasons that accelerated this disintegration. Another significant factor in the international area was and still is the USA. The attitude of the USA to Yugoslavia would be re-shaped with the event that took place in the region. With the decision taken by the American National Security department, a continuation of Yugoslavia would be supported with the integration of a free-market economy. However, this policy had a change with the events later on. In this sense, 
the reasons behind the disintegration of Yugoslavia can be divided into two as domestic and foreign reasons. My hypothesis is that the most important reason for the breakup of Yugoslavia is directly related to the developments in the country, rather than external factors. In this article, the following

\section{Domestic Reasons}

\subsection{Economic reasons}

When it is looked at the reasons behind the disintegration of the federation, the fact that economic factors had an important role cannot be denied. As Yugoslavia fell into conflict with the Soviets, it became dependent on the west for economic and military support. Economic reforms were made in the early 1950s. Earnings of republics were transferred to federal funds and the federal funds distributed these earnings. This affected developed or underdeveloped republics because the more developed republics were unwilling to give their earnings to less developed ones. And this led to negative reactions from other republics. (Görmez, 2013, pp, 63), And this meant that the principle that Yugoslavia was a solidarity-based country was ignored.

The 1980s were difficult years for the Yugoslavian economy. While Yugoslavia was experiencing modernization. it was, on the other hand, experiencing a decrease in the number of agricultural workers. The most important reason behind this was the migration of rural people to cities. While $73 \%$ of the population lived in rural areas in 1948, in 1981 only $27 \%$ of the population lived in rural areas. This is one of the most important reasons for the rising unemployment problem in cities. This situation led to important problems such as a decrease in agricultural efficiency and increase in unemployment problems in cities. These economic problems led to the emergence of two structures in the country.

Economic decentralization in the Yugoslavian economy between the years of 1960 and 1970 led to conflict between reformists and conservatives. (Friedman, 2004, s. 28) This would increase the disturbances in the country and lead to delay of the planned reforms. As a result of this, Yugoslavia would declare its economic crisis in 1985. When the data about Yugoslavia is studied, it is seen that the gross national product in 1985 saw a decrease of $5.5 \%$ compared to 1979 , and the foreign debt was 15 billion dollars. And the inflation rate was about 400\%. (Görmez, 2013, pp,64)

Yugoslavian federation can be divided into two in terms of economy as North and south. When it is looked at the northern part, it can be seen that Slovenia and Croatia. And in the southern part are Macedonia, Montenegro, Serbia, and Bosnia-Herzegovina. (Hodson, Sekulic, \& 
Massey, 1994, pp, 1539) When the two parts are compared, the countries in the northern part were developing more rapidly in the economic sense than the countries in the southern part. This led to a dilemma. The northern part did not find the economic developments in the poor southern part sufficient. They thought that this situation affected their own development negatively. And the countries in the southern part claimed that Croatia and Slovenia did not aid them enough in the economic sense. (Marolov, 2000, pp, 250-251, Jovic, 2001)

This situation would break the solidarity within the federation. As the development in Slovenia and Croatia was larger compared to others, they had a chance of swift entrance to a full market economy. However, other republics desired an economy model mixed with some appearances of marketing. However, Croatia's and Slovenia's shares in the economy were increasing gradually. And this led to conflict and an argument which suggested that; these countries were using the funds they receive in a better way. (Schuman, 2004, pp, 35; Friedman, 2004, pp, 28-29, Jovic,2001) The claim that shared funds with Croatia and Slovenia were used more efficiently was going to accelerate the disintegration in the country. The countries which were already poorer compared to Croatia and Slovenia were going to be considered as obstacles.

As a matter of fact, when the export shares are studied, it is seen that this argument was correct. When the share percentages and per capita income within the Yugoslavian federation are studied, Slovenia's share in export was $29 \%$, and it's per capita income was 12.500 US dollars and the runner-up Croatia's export share was $21 \%$ and it's per capita income was 7.100 US dollars. When we look at the other countries within Yugoslavia, export share in Serbia was $21 \%$ and its per capita income was nearly 4.950 US dollars, Montenegro's export share was approximately $2 \%$ and its per capita income was 3.950 US dollars, Bosnia Herzegovina's export share was $14 \%$ and its per capita income was 3950 US dollars, Macedonia's export share was $4 \%$ and its per capita income was 3.330 US dollars, and Kosovo's export share, as the poorest part of the federation, was $1 \%$ and the per capita income was 1.520 US dollars. (Neziroğlu, 1994, pp, 19) This situation was an advantage for Slovenia and Croatia because these two countries were already in a different economical position from other republics. Export shares of these two countries were almost equal to the sum total of the rest.

Economic inequality was going to dig Yugoslavian Federation's grave. Actually, the attempts to refresh the economy after 1945 were better than the situation before the war. However, inequality in the federal state was going to lead to conflict between republics. Industrialization and 
agricultural developments in Croatia and Slovenia were expanding the economical gap which was already present. Investments in tourism and industry were bringing a lot of income to these two countries. In order to provide a balance within the federation, it was aimed to transfer money from the riches parts to the poorest parts to develop the poor parts. In addition to this, it was aimed to make investments in poor republics. But this did not yield successful results, because these attempts led to the rise of jealousy and different policies in the country and the disintegration became more clear. (Crietchley, 1993, pp, 445)

The economic crisis transformed potentially modern social relations in the society into the race and religion-related ties, and trade relationships that exist in the region instead of modern ties. Because of these developments, internal opponents had to struggle with external opponents to prevent the interests of the ruling elites. Internal opponents struggled with opponents because of the dissatisfaction with their living standards and because they considered the interests of the elites as economic threats. It can be said here that the disintegration of Yugoslavia is the result of a socialist society's transition into macro-economy. (Friedman, 2004, pp 29-30)

\subsection{Multi-National Structure}

Yugoslavia was able to keep different ethnic groups together for a long time. The main reason for this is the cultural and economic rights of the groups forming the community such as Turks and other minorities. Another important reason was that the country had a strong leader like Tito. However, especially after the death of Tito, a number of deteriorations would occur in this structure. This would lead to the emergence of different states within Yugoslavia, which was already in the process of demolition.

When the Balkan history is examined in general, it will be understood that the Balkans is a place formed by a mix of Illyrian tribes with Turkish and Slavic people. This ethnic structure would take its final shape especially when the Ottoman state comes to settle in this region. But, as time progresses, nationalism in $19^{\text {th }}$ would begin to spread among the ethnicities living in the region and the ethnic groups here would have willing to keep their own past, traditions, and customs. Therefore, this multi-ethnic structure would be shown as one of the important reasons for the collapse of Yugoslavia, along with the economy. (Tekin, 2012, pp, 9, Jovic, 2001)

It will be useful to give the population rates of republics within the former Yugoslavia federation in order to make it easier to comprehend clearly. According to the numbers of the year of 1991, Slovenia's 
Yağcı, S. (2019). Internal and External Reasons of The Breakup of The Yugoslavia. ABAD, 2(4), 245-258.

population was 1.9 million and it consisted of $90 \%$ Slovenes, $\% 3$ Croats, $2 \%$ Serbs and $5 \%$ others. When it is examined the population of Croatia, the total number of populations of Croatia was approximately 4.7 million. With a total number of populations, Croats formed $75 \%$, and Serbs formed $12 \%$ of the population. when it comes to Serbia, $65 \%$ of the total population was to consist of Serbs. The second majority was in the hand of Albanians with the rate of $20 \%$ and Croats' rate was only $2 \%$. The country with the most complex population among these was BosniaHerzegovina. In Bosnia-Herzegovina where the total population was around 4.3 million. The rate of Muslims was $44 \%$ within the population. Serbs were the second rank in the population with $31 \%$ and lastly, Croats formed only $17 \%$ of the population. Montenegro's population was as follows: Total population was around 613 thousand, $68 \%$ of this rate was Montenegrins. The Muslim population was $13 \%$ in the whole rate. The rest was with $6 \%$ Albans and 3\% Serbs. When looking at Macedonia, $67 \%$ of the total population was Macedonians, $20 \%$ was Albans, $2 \%$ was Serbs, $7 \%$ was Turks and $11 \%$ was other autonomous republics. Lastly, the majority of the population in Kosovo was Serbs. (Neziroğlu, 1994, pp, 20)

If the ethnic diversity in the country is to be examined in more detail, it will be seen that Germanic cultures were influential on Slovenes and Croats. Because these two groups felt closer to the west because of the interaction experienced in the historical process. The Croats are a separate branch of the Slavs. Croats, especially as a result of their close relations with the states of Italy, Austria, and Hungary, were in constant interaction with these people. Croats, who became Catholic with the influence of the Vatican, developed a mixed culture of Mediterranean and Central European. (Tekin, 2012, pp. 11; Akgönenç, 1992, pp, 37-38)

The Serbs were in a leadership struggle dating back to the Xth century. They interacted more with Macedonia and Greece due to their geopolitical position. Unlike Slovenia and Croatia, their historical and cultural development was shaped into an East-Mediterranean type due to their intense relations with the east. Especially as it was seized by the Ottoman state, Serbia met Turkish-Islamic culture. To say how effective the Turkish - Islamic culture is in Serbia, it is a matter to be investigated. However, although Serbs did not convert to Islam, it is obvious that they were exposed to this culture due to the interaction. In this sense, as a result of the relations established throughout history, both the friendship and enmity of Serbia are deeply rooted ones. (Tekin, 2012, pp, 11)

Although the Slovenes are in fact a branch of Slavs, they were under the influence of Germany and Austria just like Croats. The experiences and 
interactions within the historical process have led them to act like European people. The Catholic Slovenes have mainly acted in alliance with central and western Europe and believed that this attitude would be more appropriate for their own structure.

Slavs who converted into Islam had an active presence in the Balkans. In particular, the Bosniaks were followers of the Bosnian Church of Christianity before accepting Islam. Over time, Bosniaks converted into Islam and Islam became a way of life as a result of the Ottoman state's effective advancement in the Balkans. In this sense, it can be said that Bosnians were shaped in the frame of Turkish-Islamic culture. The Albanians and Macedonians were spread over a wide area of the Balkan region. This situation made it difficult to control them. (Okiç, 1973, pp, 210)

\subsection{Nationalism Movements}

Towards the end of the 1980s, everyone had begun to expect the collapse of Yugoslavia. The system which gave broad authorities and rights to the units that formed the federation would lead to the strengthening of nationalism and the collapse of the unity and solidarity in the country. Especially in the face of Slobodan Milosevic's conservative and nationalist stance, the majority of Serbs began to support Milosevic. In contrary to this, the other republics within the country tried to hold their own stances towards this nationalism. This was one of the factors that accelerated the disintegration. (Cretu, 2006, pp, 20)

After the death of Tito, the corruption in Yugoslavia surfaced, and people living under the same roof embarked on a different quest. These different quests would then lead to independent states. However, Serbian nationalists realized this dissolution and published a statement between the years of 1985-86. This statement was penned by Serbian Academy of Arts and Sciences. This statement which was accepted as a kind of program of Serbian nationalism caused a huge excitement and concern. Especially the Serbs welcomed it, while the other nations living under the Yugoslavian Federation regarded it unacceptable. When the memorandum is examined, we see that the following important topics were discussed;

i. For decades, Serbia has been prevented from expressing its national identity within the Yugoslavian federation. With the boundaries drawn by Tito, the majority of the Serbian population has been forced to live outside Serbia.

For decades, the identity of Serbs has been prevented from expressing within Yugoslavia. A vast majority of people living in Serbia had forced to live outside Serbia, with the boundaries drawn by Tito. 
Yağcı, S. (2019). Internal and External Reasons of The Breakup of The Yugoslavia. ABAD, 2(4), 245-258.

ii. Serbia's political unity and integrity have weakened because of the recognition of Vojvodina's and Kosovo's autonomy

iii. Serbs in Kosovo are being done genocide by Albanians

iv. Slovenia and Croatia are intentionally harming Serbian economy. (Taşar, Metin, \& Ünaltay, 1996, pp, 120-121)

The declaration mentioned that Serbs were subjected to discrimination within the Yugoslavian federation, that there was pressure against the Serb, and that, most importantly, they did not have enough rights. The Memorandum also claimed "the system established" by Tito and Kardelj (one is Croat and the other is Slovene) worked in favor of the two northern republics. This statement meant that an assimilation policy was being applied against Serbs, especially in Croatia. (Banac, 1992, pp, 15) This memorandum caused to increase the nationalistic sentiments among the Serbians and invited them to revolt.

While these developments were taking place in Yugoslavia, Milosevic attempted to increase the nationalistic sentiments among the Serbs. For example, on the 600th anniversary of the 1st Kosovo war, he went to the war place, calling to about a million Serbs there, and emphasized that no ethnic group would be able to harm Serbia from then on. (Tekin, 2012, pp, 19) Also immediately after his visit to Kosovo, he canceled Kosovo's autonomy as soon as he returned to Belgrade. The reason for this cancellation was explained with an emphasis on unity and solidarity. After these dates, Milosevic tried to increase the emotional intensity among Serbs, especially by emphasizing the crimes committed against the Serbs. The speech which Milosevic gave by referring to the war in Kosovo was directly or indirectly against the Muslim population in Yugoslavia. With this speech, he tried to suppress the Muslim population. In this way, he attempted to suppress the groups, who especially felt that they belonged with the ottoman state, through intimidation.

In $14^{\text {th }}$ Congress of League of Communists of Yugoslavia gathered in 1990, Slovenian and Croatian delegations left the Congress in spite of the promise of "maintaining unity", which they had emphasized before, gave the message that Slovenia and Croatia wanted to become independent states. Milosevic now knew that the only way was to foster a sense of nationalism among the Serbs. As a matter of fact, in the first multi-party election held on December 8 in 1990 in Serbia, Milosevic's party SSP won the election with an overwhelming superiority (by taking $77.6 \%$ of parliamentary seats). And again, Milosevic was elected President of the Republic by winning the majorities of votes $(65.34 \%$ ). (Cretu, 2006, pp, 22) 
There were rumors that some republics, especially Croatia and Slovenia, were going to leave the federation; because these two states were the most powerful ones within the Yugoslavian federation in terms of economy. Because of this, Milosevic would begin to work to prevent the disintegration of some parts, if not all, of Yugoslavia.

\section{External Factors in the Break-up of Yugoslavia}

\subsection{USA's Approach}

When the US policy about Yugoslavia's disintegration is examined, it is seen that the US avoided having an active policy throughout the disintegration process. Especially with the end of the cold war, Yugoslavia's importance for the western countries and the USA had decreased. The fall of the Berlin Wall in 1989 led to the end of the bipolar world, and perception of disarmament and world peace prevailed. But it would be seen later that the end of the cold war would not prevent disarmament, nor would the conflicts around the world end. The Balkans is the most vivid evidence of this.

The US's interest in the Balkans is an old one, but its plans for the region date back to 1980 s. USA National Security Resolution Directive issued by the US in 1984 which was labeled "sensitive confidentiality" was titled the United States Policy on Yugoslavia. When this document is examined, it is understood that the strategic purpose of the United States was to include the Balkans and Yugoslavia in the free market system. As understood from what is written in the directive, the policy of the United States about Yugoslavia was to integrate Yugoslavia into the world system and bring it closer to the west. (Bora, 1995, pp, 193) Because a stable and militarily powerful Yugoslavia could stand in the way of any power which could be a threat to the west. The threat mentioned here is USSR. Yugoslavia was a major obstacle in front of the Soviet expansion and hegemony in Southeast Europe. The US wanted to keep the Yugoslavian federation alive in every sense. The US states that the economic situation Yugoslavia is in is a disadvantage for them. As a solution to this, Yugoslavia should be supported in terms of the military and especially in terms of economy. In addition, the US had to integrate the free economy market into Yugoslavia in the long run. As it can be deduced from the report, the focus was on how to develop the economic life of Yugoslavia and how to integrate it into the West. Another important issue was the military. As Yugoslavia was one of the most important states in the expansion of the USSR, military aid was especially emphasized, and it was stated that the required necessities would be supplied. (National Security Decision Directives, 1984) 
Yağcı, S. (2019). Internal and External Reasons of The Breakup of The Yugoslavia. ABAD, 2(4), 245-258.

The fact that the US was not active in Yugoslavia's disintegration process does not mean that it was not aware of what was happening in Yugoslavia. For example, Eagleburger went to Yugoslavia in February 1990. Eagleburger who knew the characteristics of the region well because he was an ambassador there and the report he wrote when he returned to the US is an important proof of how closely Yugoslavia was followed. "You had told me that the situation was bad there and it would be worse and worse every day. Well, I'd like you to know that the situation is a lot worse than you thought and there will be a lot more blood-shed than expected.').(Halberstam, 2001, pp, 32)

Until 1991, the US policy about Yugoslavia did not contain an active fight. The reasons are as follows: The first is that Iraq invaded Kuwait on 2 August 1990. This war caused the United States, the only superpower after the Cold War, to direct its power to there. This caused the US policy to shift to the Middle East. The second reason is the intense diplomatic contact with the USSR. David Halberstam explains this in his book as follows: "when the first sure signs of the Soviet Union breakup became clear, and when American influence there might have been at its greatest, we were wedded to Gorbachov. The Soviet Union and the eventually Russia, as far as Bush and the men around him were concerned, was like a baby in an oxygen tent, entering its own life tentatively and awkwardly. As that process took place, Yugoslavia was very much a peripheral issue in Washington. Already there were signs of the immense benefits to be derived from the change in Russia-American relations. Russia had been an invaluable ally in the Gulf War, with Gorbachov greatly angering his own military people, who were closely wedded to Saddam Hussein. Moreover, with Gorbachov and Edvard Shevardnazdze's uneasy acceptance Germany was on its way not merely to unification, but unification within NATO, a geopolitical coup unimaginable a few years earlier. (Halberstam, 2001, pp, 33)

Another important reason was that the situation in Yugoslavia did not require military intervention. In 1991, foreign minister James Baker said in the report he submitted to Washington that he believed they had time until military intervention. Therefore, it would be more appropriate to shift the forces to the side rather than taking part in an active struggle. (Emroğlu, Çakır, 2008, s, 94)

In summary, the United States preferred to stay away from the conflict during the disintegration of Yugoslavia. But that does not mean that the US had literally isolated itself from Yugoslavia. It developed relations in the direction of the information given above. However, it is difficult to 
Yağcı, S. (2019). Internal and External Reasons of The Breakup of The Yugoslavia. ABAD, 2(4), 245-258.

say whether the US played a unifying or separating role in the disintegration process.

\subsection{Relations with USSR}

The Balkans has always been a place of vital importance for Russia, both in terms of socio-cultural and of geopolitical position. For this reason, it can be said that the Balkans is an inseparable part of the Russian in the political sense. The Russian Federation, which replaced the USSR in 1991, could not produce or be not in a position to produce an active policy in Yugoslavia's disintegration process. In general, it acted together with international organizations rather than being in the program directly. To explain it a bit further, the Yugoslavian issue was seen as an unpleasant obstacle preventing Russia from joining the civilized world. In 1990, the USSR government approached the crises taking place in Yugoslavia cautiously. (Lo, 2003)

The USSR's policy was the same as that of the US, but the US was a little more active than Russia. In this period, the Kremlin's foreign policy was not indexed to Yugoslavia, as it was difficult for Kremlin to be active in foreign policy while it was dealing with the domestic problems in the early 1990s. While the crisis continued to climb in 1991 and steps were being taken to become an independent state, the USSR did not take the necessary positive steps, although it sided with Yugoslavian Federation's territorial unity. Later, however, the US and NATO's role in the region with an active policy would draw Russia's attention and lead it to play a more active role in international organizations. Especially after the Dayton Peace Treaty was effective, Russia started a process of restructuring in foreign policy as the treaty led to developments against Russia. Russia then saw NATO as an organization working against itself. (Lo, 2003)

\subsection{Non -Aligned Movement}

The Cold War, a product of power struggle between the US and the USSR after World War II, caused the emergence of a bipolar competition by transforming the structure defined as the international system. In the new equation, other states have sought alliances for various reasons such as security concerns, ideological, cultural and economic norms and finally they have positioned themselves in one of the poles. Accordingly, while entering the second half of the $20^{\text {th }}$ Century, the most important reflection of this paradigm shift is that the system has come to the point of being separated by absolute lines as East/West. (akademikperspective.com.tr, 1013)

The Non-Aligned Movement, which it can be called a third block, has emerged in such a polarization process. Thanks to the liquidation of 
colonialism, states that have gained their independence have primarily aimed at economic development rather than being involved in the tense environment of the Cold War and within this framework, they tried to pursue policies aimed at ending imperialism with underdevelopment. The Non-Aligned movement was established when the collision of the colonial system and the cold war were at a high point during the independence struggles occurred in Asia and Africa. The number of members was 24 at the beginning but this figure reached up to 120 with a huge amount of increase. This nearly constitutes almost more than half of the entire population in the world. The main points of the movement were the sovereignty, territorial integrity, the common struggle against a new colonial movement such as racism and imperialism.

The foundation basis of Non-Aligned Movement was laid during Bandung Conference in 1955. Upon the call made by Indonesia, the states namely Burma (Myanmar), Ceylon (Sri-Lanka), India and Pakistan participated in the meeting held in Bogor. Within the framework of targets determined at the meeting of Bogor, Bandung Conference was held on 18 April 1955. As a result of this meeting, many resolutions were taken.

But the most important ones are: to live together in peace, to support national independence movements, not to participate in military and political alliances, and finally not to make regional defense pacts and military agreements are the most important decisions that come to the conclusion of the meeting.

However, officially, the Non-Aligned movement started in 1961. The first organization of Non-Aligned Movement under the leadership of Tito shall take place with the participation of twenty-five governments thanks to Belgrade Conference to be held on between September 1 and 6, 1961 and Non-Aligned Movement shall have arisen. The founding fathers of the Non-Aligned Movement were Achmed Sukarno as the first Indonesian President, Jawaharlal Nehru as the first Indian President together with Josip Broz Tito from Yugoslavia and Gamal Abdel Nasser from Egypt. This movement, along with the involvement of Yugoslavia, begin to increase the effectiveness of Tito in the international arena. Tito sought new allies to ensure their safety with the disintegration of the Soviet Block. As a matter of fact, he established relations with the countries affiliated to Non-Aligned movement prior to Belgrade Conference. However, after 1960s Yugoslavia began to strengthen its international prestige significantly. Because the most important sign is that both the USA and the Soviet Union requested help from the evolving block of independent nations led by Tito. Non-Aligned Movement has 
adopted principle to follow up an active policy instead of a passive policy and to deal with the global problems rather than acting regionally. In this direction, Tito benefited from the advantages of this movement and expanded own policy up to Arabic Countries with which it has never kept in contact before. In this direction, the Palestine Liberation Organization was supported against Israel.. (country-data.com.tr, 1990)

Tito developed relationships with Third World countries to increase his power in the international arena. He tried to establish a close relationship with China against the Soviet threat. Because at that time, China, the leader of the Communist world, was the enemy of the Soviet Union and it was in the integration process with the West. During the 1970s, Yugoslavia succeeded to be a moderate power. Especially under the leadership of Tito, the number of Non-Aligned Movement increased from 25 to 117. However, with the death of Tito in 1980, Yugoslavia lost its control to Cuba. However, it assumed a new important task at the $18^{\text {th }}$ meeting in 1986 and it was resolved to hold the $19^{\text {th }}$ meeting in Belgrade and thus Yugoslavia re-gained the chairman up to 1992. The basic role of Yugoslavia in the Non-Aligned Movement in 1980 was to act as the intermediary for conflicts between Third World countries between Iran and Iraq because of the fact that Yugoslavia was worried about oil supply. The non-aligned policy of Tito became valid also after his death. Although Yugoslavia hosted the meetings and called the chairman back, because of the events that would develop in Yugoslavia, Yugoslavia would enter the process of disintegration and would actually be deleted from the stage of history. (country-data.com.tr, 1990)

Thanks to the non-aligned movement, Tito moved his power from a regional basis to the international platform. As a result of Tito's initiatives and mediation between countries, the political influence of Yugoslavia has expanded from the Middle East to Asia, from Africa to Latin America. As a result, the Non-Aligned Movement is a result of the struggles of independence in the colonies and of the Cold War polarization. In other words, it happened in a natural process in the ordinary course of history. Indeed, during the peak of the Cold War in the middle of the 20th century, there were only two choices in front of the states that newly won their independence; getting involved in one of the blocks or entering a new formation by remaining out of the block. Most of these states preferred to stay out of the said

\section{Conclusion}

There are many reasons why Yugoslavia collapsed after Tito. However, the most important one among them is directly related to the developments in the field of economic and cultural differences. As 
known, Yugoslavia consisted of different ethnic groups and religions. Especially, Slovenia and Croatia were quite a different background. Their interaction had always been with the west. Accordingly, they considered themselves as a part of western rather than east. In addition to this, economic crises and inequality in income escalated the existing problems between the republics. Actually, rather than being known, external factors played a less significant role in this process. Due to the developments in the world, states called Super Power did not find a chance to involve in the Balkans.

\section{References}

Akgönenç, O.M.( 1992). Bosna-Hersek Güney Slavlar Birliği Dağglırken. Silahlı Kuvvetler Dergisi. Vol. 111. No. 334.

Banac,I.(1992). The Fearful Asymmetry of War : The Causes and Consequences of Yugoslavia's Demise. Deadalus, 121 (2), 141-174

Bora,T.(1995).Bölgeler-Sorunlar-

Yugoslavya:MilliyetçiliğinProvakasyonu.İstanbul:Birikim Press

Cretu, Valeri. "Soğuk Savas Sonrasinda Rusva Federasvonu'nun Yugoslavva Krizlerine Yönelik Politilkası". MA Thesis, Ankara Üniversitesi,2006

Crietchley, W.H.(1993). The Failure of the federalism in Yugoslavia, International Journal, Volume, 48. No,3, p,434-447

Çakır, M.F., Emroğlu, H.(2008). Yugoslavya'nın Dağılma Sürecinde Ttansatlantik Dış Politika Parametreleri(1990-1995). Avrasya Etütleri, 2008, Volume, 33, No,1, $\mathrm{P}, 83-112$

Friedman, F.(2004). Bosnia and Herzegovina: A Polity on the Brink.London : Routledge Press

Görmez, A.B."The Formation of Bosniak Nation." MA Thesis, Middle East Tehnical University, 2013

Halberstam, D.( 2001). Barış Zamanı Savaş.(Trans. Abdullah Y1lmaz). İstanbul : Türkiye İş Bankası Press

Hodson, R., Sekulic,D \& Massey ,G.(1994). National Tolerance in the Former Yugoslavia. American Journal of Sociology, Vol,99, (6), 1534-1558

Lo, Bobo.(2003). Vladimir Putin and the Evolution of Russian Foreign Policy. London : Blackwell Publishing

Marolov, D.(2000). The Reason for the Collapse of Yugoslavia. International Journal of Sciences: Basic and Applied Research (IJSBAR).250-258.

Metin,B., Ünaltay, A., Tașar, M. M.(1996). Bosna-Hersek ve Postmodern Ortaçağa Giriș. İstanbul : Birleşik Press

Neziroğlu, İrfan.(1994). "Yeni Dünva Düzeni ve Bosna-Hersek Cumhuriveindeki Savas." Dissertation, TBMM Kütüphane Dökümantasyon ve Tercüme Müdürlüğü

Okiç,T. (1973). Balkanlarda Bogomilizm Hareketi ve Bunun bir Araştırmacısı : Aleksandar Vasljeviç. İslam Tetkikleri Enstitüsü Dergisi, 5 (4), 205-222

Schuman, M.(2004). Bosnia and Herzegovina. New York : Facts On File Press.

http://www.countrv-data.com/coi-bin/auerv/r-14914.html. 